\title{
Principles Governance In Management Water Supply and Community-Based Sanitation (PAMSIMAS) In Banglas Barat Village Tebing Tinggi Subdistrict Kepulauan Meranti Regency In 2014-2016
}

\author{
Sukarman \\ Department of Government Science \\ University of Riau \\ Pekanbaru, Indonesia \\ nandoarman5@gmail.com
}

\author{
Baskoro Wicaksono \\ Department of Government Science \\ University of Riau \\ Pekanbaru, Indonesia \\ wicaksonobaskoro@gmail.com
}

\begin{abstract}
The research based on the selection of target villages of PAMSIMAS in Banglas Barat Village 2014-2016 accordance with Decree of Minister of Public Works No. 79 / KTPS / DC / 2013 on Stipulation of Regency / City Provision of Community Based Drinking Water and Sanitation Program, based on water Drinking and sanitation are still minimal in Kepulauan Meranti. The research leads to the principles of governance in the management of PAMSIMAS in Village Banglas Barat. The purpose of the research is to know the principles of governance in the management of PAMSIMAS in Banglas Barat Village. The type of research is descriptive with qualitative approach. The type of research data are primary and secondary data. Techniques of data collection in the research are documentation and interviews. Techniques of data analysis are descriptive qualitative. The result of the research show that the principle of governance in PAMSIMAS program management in Banglas Barat Village has not optimally. This is visible from several principles of governance accountability and rule of law can not be applied by the manager PAMSIMAS, in the operational and maintenance of PAMSIMAS assets. The right solution to solve the problems in PAMSIMAS management in Banglas Barat Village are PAMSIMAS management especially BPSPAMS should be more optimal in applying the principles of governance by coordinating all parties involved in PAMSIMAS program and supported by budget from Village Government and Local Government.
\end{abstract}

Keywords - Principles Governance, management PAMSIMAS, and integration

\section{INTRODUCTION}

The Community Based Drinking Water and Sanitation Program (PAMSIMAS) is a concrete and central government (central and regional) action program, to improve access drinking water and sanitation services for the rural poor and to create clean living behavior through the promotion of environmental health and the provision of drinking water infrastructure and sustainable community-based sanitation.
PAMSIMAS Program in 2014, Kepulauan Meranti Regency gets the target villages allocation from APBN as much as 4 villages and the target villages allocation from regency's APBD as much as 1 village. The realization of this project reviewing the Decree of the Minister of Public Works Decree No. 79 / Kpts / DC / 2013 about Stipulation District / City Target of the Community Based Drinking Water Supply and Sanitation Program.

Banglas Barat Village is one of the villages that gets PAMSIMAS program, with APBN funding source. In the problems identification and situation analysis had found data on population and drinking water access and early sanitation of Banglas Barat Village communities, they are:

Table 1. the population and access to sanitation and drinking water facilities

\begin{tabular}{|c|l|c|c|c|}
\hline \multirow{2}{*}{ No } & \multirow{2}{*}{ Hamlet } & \multirow{2}{*}{$\begin{array}{c}\text { Househ } \\
\text { old }\end{array}$} & \multicolumn{2}{|c|}{$\begin{array}{c}\text { The household with early } \\
\text { access }\end{array}$} \\
\cline { 4 - 5 } & & $\begin{array}{c}\text { Drinking } \\
\text { water }\end{array}$ & $\begin{array}{c}\text { Sanitation } \\
\text { facilities }\end{array}$ \\
\hline 1 & Rintis & 346 & 245 & 265 \\
\hline 2 & Perumbi & 330 & 353 & 427 \\
\hline 3 & Bandar Suir. & 280 & 98 & - \\
\hline 4 & Semulut & 85 & 23 & - \\
\hline \multicolumn{2}{|c|}{ Total } & 1.041 & 719 & 629 \\
\hline
\end{tabular}

Source: RKM PAMSIMAS, 2014

PAMSIMAS funds in Banglas Barat Village come from APBN Rp 228,000,000, Community Contribution (In-Cash) Rp 11,400,000 and Community Contribution (In-Kind) Rp. $45,600,000$ total budget is $\mathrm{Rp} 285,000,000$. The condition of Banglas Barat Village with the low access of drinking water and sanitation facilities makes the PAMSIMAS managers optimize the implementation. In the implementation of PAMSIMAS program in Banglas Barat is expected to improve healthy life behavior, stop defecating haphazardly, 
strengthening for local government, access to drinking water and sanitation services, But from the implementation of this PAMSIMAS program even causes other problems include:

- Bad management of PAMSIMAS facilities, after several months of inauguration has been unable to fulfill the community needs. This is seen in rintis hamlet, which is difficult to get water because of the many PVC connections in rintis hamlet are damaged. So it impacts on community habits such as not washing hands with soap again and defecate haphazardly until the community health condition has no improvement in the life quality.

- Lack of routine activity to monitoring the sanitary awareness level and Clean and Healthy Life Pattern (PHBS) for targeted schools and communities.

- The disappointment of the community on the PAMSIMAS management makes some people do not want to pay the fees so that the manager harms and expenses himself for operations.

\section{A. Formulation of the problem}

The PAMSIMAS program in Banglas Barat village has caused many problems in the community and the goal to empower the community by improving healthy life behavior, stop defecating haphazardly, improving local institutions and drinking water and sanitation services can not be realized. Therefore, the role of PAMSIMAS managers is very important, the author concludes the problems in this research are: How is the implementation of Principles Governance in Management PAMSIMAS in Banglas Barat Village Tebing Tinggi Subdistrict Kepulauan Meranti Regency?

\section{B. Theoretical framework}

\section{a. Theory of Governance}

Governance is defined as the mechanisms, practices and procedures of governance and citizens managing resources and solving public problems. In the concept of governance, the government only becomes one of the actors and is not always a decisive actor. The implications of the role of the government as a development as well as provider of services and infrastructure will shift into the driving force of creating an environment that is able to facilitate other parties in the community. The concept of governance refers to institutions, processes, and traditions that determine how the authority is organized, decisions are made, and citizens' voices are heard. (Sumarto Hetifa Sj, 2003)

Governance is an activity or process and governance as a manifestation of socio-political interaction between government and society in various fields related to public interest and government intervention on those interests.
(Sedarmayanti, 2003). According to Bhatta (syakrani, 2009) explained that there are four main principles in good governance namely accountability, transparency,participantin, and rule of law.

\section{b. Theory of Integration}

According to Emile Durkheim (Soerjono Soekanto) in the study of social integration explained that social integration can be realized if there is interdependence between the specialized part. In this case solidarity is based on the similarity in trust and value are functionally interdependent in a heterogeneous society.

\section{RESEARCH METHODS}

Researchers use a qualitative approach. Qualitative research is intended as a type of research whose findings are not obtained through statistical procedures or other forms of calculation. (Anselm Strauss \& Juliet Corbin, 2003).

\section{A. Research Sites}

This research was conducted in Kepulauan Meranti Regency. While the object of this research is Community Based Drinking and Sanitation (PAMSIMAS) Program in Banglas Barat Village, Tebing Tinggi Subdistrict, 2014-2016.

\section{B. Data Type}

\section{a. Primary data}

Primary data is a source of information that can be obtained from direct sources or information from people who are in the field. In this case the author looks for research data to POKJA AMPL Kepulauan Meranti, BPSPAMS Managers, Facilitator Team and Society.

\section{a. Secondary Data}

Secondary data is information which obtained from other parties outside the location or object of research. These data sources can be obtained through internal data on research objects such as documents, files that are relevant in answering research problems. Then the external data derived from literature study by searching data through books, journals, papers, internet media and so on.

\section{Data Source}

Sources of research data is obtained from:

\section{a. Informant research}

They are POKJA AMPI Kepualauan Meranti Regency (head of BAPPEDA Physical Section, Head of Public Works Department of Cipta Karya, and Head of Environmental Health Problem of Health Department), Community Facilitator Team, Banglas Barat Village Chief, BPSPAMS manager and Community beneficiaries. 


\section{b. Supporting documents and reports}

Those are reports such as Community Work Plan (RKM), Community Joint Regulations with BPSPAMS managers, and PAMSIMAS financial reports

\section{Data collection techniques}

Data collection techniques are closely related to the research methods used. The instruments in collecting these data are :

\section{a. Documentation}

It is the technique of collecting data through the documents that exist on the location of research and outside research.These documentation materials are reports that are relevant to the research problems of the relevant agencies.

\section{b. Interview}

To obtain information from informants required in-depth interviews using purposive sampling interview techniques means interviews of selected people based on the author's knowledge of people who know more about research problems.

\section{RESULT OF RESEARCH AND DISCUSSION}

Management of PAMSIMAS Program in Banglas Barat Village, Tebing Tinggi Subdistrict, Kepulauan Meranti Regency.

\section{A. Background of PAMSIAMS Program in Regency Kepulauan Meranti}

Decision making in the PAMSIMAS program Kepulauan Meranti Regency involves several government agencies, they are BAPPEDA, Health Department and Public works department of Cipta Karya. The PAMSIMAS program at the village level has several stages from the village selection stage, planning, implementation, operation and maintenance. Some stages of PAMSIMAS program in Banglas Barat Village are:

\section{a. PAMSIMAS program planning stage}

\section{The planning stages consist of:}

- Problem identification and situation analysis

- Behavior change behavior

- Establishment of Community Self-Help Groups (KKM) and Implementation Unit (SATLAK) PAMSIMAS Program

- Collection of contributions

- Preparation of RKM and RKM verification

\section{b. Implementation phase PAMSIMAS}

The implementation stage, the process of disbursement of Community Direct Assistance (BLM) funds from APBN is done through three stages, stage I $20 \%$, stage II $40 \%$ and stage III $40 \%$. The construction of the facilities carried out in the form of workmanship of PAMSIMAS water tower and drilling of drilled wells for two points

\section{c. Operational and Maintenance Stage}

The community contribution in PAMSIMAS program in 2015 based on community agreement with BPSPAMS are the community is obliged to pay Rp.10.000 /household monthly. Distribution in 2015 can only be done for 100 families that is from 36 families from Rintis Hamlet and 64 household from Bandar Suir Hamlet this is due to the ability of the water tower that cannot reach for all beneficiaries. The operation of PAMSIMAS program in 2015 is not running optimally, this is because people do not want to pay dues from water that has been distributed because people do not get water evenly. Damage also occurs in PAMSIMAS pipeline facilities, this is due to the impact of road improvement project activities in Banglas Barat Village and from the managers themselves do not maintain and coordinate with the parties concerning the PAMSIMAS pipeline.

In 2016 the PAMSIMAS program was continued by revitalizing the BPSPAMS membership due to the inactivity of the old membership. At the beginning of BPSPAMS management, the members of BPSPAMS have conducted a discussion with PAMSIMAS activists who are active in the PAMSIMAS program, which has been determined that the community agrees to apply water meter at a cost of Rp.100,000 which is paid in installments for 2 months and the amount of Rp. $3000 / \mathrm{M}^{3}$ water use. Until now the number of users or consumers of this PAMSIMAS program amounted to 54 families who came from Bandar Suir Hamlet 43 household and Rintis Hamlet 11 household.

\section{B. Principles Governance in Management PAMSIMAS}

\section{a. Participation}

The implementation of the principle of participation in the management of PAMSIMAS program in Banglas Barat Village Tebing Tinggi Subdistrict Regency Kepulauan Meranti is quite optimal, because the community has been directly involved in the process of policy programming and implementation together form a community institution.

The community began to care about the conditions encountered and began to participate in citizens discussion to form PAMSIMAS program management institution units such as KKM, SATLAK, and BPSPAMS. The community also attended and participated in PAMSIMAS program activities such as activities of problem identification and situation analysis, selection of technical options, training, and health, Discussing RKM, BPSPAMS Training, Technical Training, Administrative and Financial Training, and Implementation of CLTS and STBM. The community has also contributed the clean water facilities that have been used from the PAMSIMAS program in 2016. This is because the new BPSPAMS members have performed their duties and responsibilities 
Table 2 Financial Report of PAMSIMAS Program in Banglas Barat Village 2016

\begin{tabular}{|c|l|l|l|}
\hline No & Months & Income (Rp) & Expenditure (Rp) \\
\hline 1 & March & 6.333 .000 & 6.582 .000 \\
\hline 2 & April & 2.160 .000 & 2.268 .000 \\
\hline 3 & May & 1.497 .000 & 1.517 .000 \\
\hline 4 & June & 781.000 & 802.000 \\
\hline 5 & July & 1.159 .000 & 1.082 .000 \\
\hline 6 & August & 1.289 .000 & 917.000 \\
\hline 7 & September & 1.585 .000 & 902.000 \\
\hline 8 & October & 1.730 .000 & 1.064 .000 \\
\hline 9 & November & 1.623 .000 & 1.596 .000 \\
\hline 10 & December & 654.000 & 623.000 \\
\hline
\end{tabular}

Source: BPSPAMS report, 2016

The amount of public awareness to realize the PAMSIMAS program, so that the community gather to provide assistances both material and non-material. Barat Banglas Village community is also willing to give a piece of land size 5 x 5 Square Meters to build a PAMSIMAS public faucet, the total of the public faucet as much as 4 units. There is no mastering action from the construction of public faucet and flowing water by the communities who have given their land and they realize that it is for the public necessity.

The establishment of community institutions to solve the problems in the community that is limited clean water access and healthy living behavior so that the PAMSIMAS program expected to change the condition of community living standards. The community Efforts to solve the problem by citizen discussion, although there are differences of opinion and disagreement to seek the solution of the problem but it can be done through inter-community coordination to establish the cooperation until to form a better culture such as mutual cooperation attitude.

\section{b. Transparency}

The PAMSIMAS program is a community-based program in which communities do an important role in the management. The beginning of the PAMSIMAS program in Banglas Barat Village is considered to be quite optimal where there has been openness from the local government by disseminating the PAMSIMAS program, the people who received this program made an Interest to Participate Statement in PAMSIMAS (SPMKP).
There has been socialization in the beginning of PAMSIMAS program, and in every stages of PAMSIMAS program involving the community which means openness in terms of information about the program is known to public. In the planning stage and implementation program, PAMSIMAS has conducted a socialization about the development of facilities, and trainings.

The management of PAMSIMAS program in Banglas Barat Village as in the preparation and disbursement of RKM funds done by KKM, SATLAK, BPSPAMS and with the communities. It has done the details of activities and the use of funds totaling Rp. 285.000.000.

\section{c. Accountability}

The PAMSIMAS program managers in Banglas Barat Village in the operational and maintenance stages from 20152016 have not applied accountability principles so that this principle has not run optimally. After the transfer of PAMSIMAS assets to BPSPAMS, there is no report from BPSPAMS as PAMSIMAS program manager about the activities either to the BPD or the Village Government. BPSPAMS itself does not do its responsibility to maintain the assets of the community where 1940 meters of pipeline is damaged from a total of 3194 meters and consequenced the public water supply service is cut off and only one public faucet works from the total of the four faucet.

In 2015,BPSPAMS management members do not perform their duties and responsibilities, only the chairman and treasurer are in charge. So in 2016 the old members are revitalized because of their inactivity, and the BPSPAMS report is conveyed to the facilitator every 3 months. This proves that the manager of PAMSIMAS has not been able to carry out the principle of accountability to the maximum of the PAMSIMAS program objectives.

\section{d. Rule of Law}

The management of PAMSIMAS conducted by BPSPAMS in Banglas Barat Village, has established a joint regulation between the BPSPAMS as the manager and the people who are the beneficiaries of the PAMSIMAS program. However, the management of BPSPAMS is not able to apply the regulation, it shows an not optimal legal certainty in PAMSIMAS management. This is because the number of minimal managers and the absence of supporting instruments in the implementation of sanctions, moreover the PAMSIMAS local residents benefit minimize the occurrence of conflict so that the BPSPAMS only do an oral rebuke for people who are delinquent pay fees and collision of removing the piping networks. 


\section{CONCLUSION}

\section{a. Conclusion}

Based on the results of research and field findings on Principles of Governance in Community-Based Drinking Water Supply and Sanitation Management (PAMSIMAS) in Banglas Barat Village Tebing Tinggi Subdistrict Kepulauan Meranti Regency in 2014-2016, the researcher can conclude that the principle of governance in PAMSIMAS management cannot work or run optimally yet. This proves from the management of PAMSIMAS, The implementation of governance principles that accountability and legal certainty is still not optimal and the output of PAMSIMAS program component is still just the provision of clean water.

\section{b. Suggestion}

The advices given by the author in this research are:

- Required commitment and responsible attitude from BPSPAMS management, and the existence of clear rules or sanctions in managing PAMSIMAS program in order to carry out its main duty and function properly

- There is a need for budget support for PAMSIMAS managers from both the Regional Government and the Village Government, so that the damaged PAMSIMAS facilities can be improved and increase the number of PAMSIMAS beneficiaries.

- The community is expected to maintain and look after the facilities that have been provided and want to participate in improving the clean and healthy life behavior so that through PAMSIMAS can support the welfare in the community.

\section{REFERENCES}

[1] Hetifa, Sumarto, "Inovasi, Partisipasi Dan Good Governance," Bandung, Yayasan Obor Indonesia, 2003.

[2] Sedarmayanti," Good Governance (Kepemerintahan Yang Baik) Dalam Rangka Otonomi Daerah", Bandung, Mandar Maju, 2003.

[3] Strauss, Anselm \& Corbin Juliet," Dasar-Dasar Penelitian Kualitatif”, Yogyakarta, Pustaka Pelajar, 2003.

[4] Soekanto, soerjono, "Mengenal Tujuh Tokoh Sosiologi", Jakarta, Rajawali

[5] Syakrani, "Implementasi Otonomi Daerah dalam Perspektif Good Governance", Yogyakarta, Pustaka Pelajar, 2009

[6] Rencana Kerja Masyarakat Desa Banglas Barat Pamsimas 2014

[7] Http://www.Pamsimas.org di akses pada tanggal 8 september 2017

[8] Pedoman Umum Program Penyedian Air Minum dan Sanitasi berbasis Masyarakat 2013 